\title{
KEBIJAKAN REVITALISASI SISTEM TRANSPORTASI PUBLIK SEBAGAI LANGKAH ANTISIPATIF KEMACETAN TOTAL DI KOTA MALANG
}

\author{
Novy Setia Yunas \\ Mi'rojul Huda \\ Program Studi Ilmu Politik \\ Fakultas Ilmu Sosial dan Ilmu Politik Universitas Brawijaya Malang \\ email: novysetiayunas@gmail.com
}

\begin{abstract}
ABSTRAK
Penelitian ini bertujuan untuk memformulasikan kebijakan revitalisasi sistem transportasi publik sebagai langkah antisipatif kemacetan total di Kota Malang. Kemacetan merupakan sebuah permasalahan yang cukup krusial dan pelik yang pasti dihadapi oleh sebuah kota besar. Salah satunya adalah kota Malang yang saat ini mulai merasakan kemacetan di berbagai titik. Banyak yang memprediksi kemacetan di Kota Malang akan bertambah parah seperti halnya di kota besar lainnya misalnya DKI Jakarta. Kemacetan parah di masa yang akan datang tidak akan terjadi jika mulai saat ini pemerintah lebih responsive dalam mengambil sebuah kebijakan revitalisasi sistem dan sektor transportasi publik yang ada. Kebijakan revitalisasi sektor publik di kota Malang sudah selayaknya menjadi sebuah kebijakan antisipatif dalam rangka mengantisipasi kemacetan yang lebih parah di masa yang akan datang.
\end{abstract}

Kata Kunci: Kebijakan, Formulasi Kebijakan, Transportasi, Kemacetan

\section{ABSTRACT}

The study aims to formulate a policy of revitalization of public trasnportation system as the total jammed anticipative steps in Malang. Traffic congestion is a problem that is qute crucial and quaint that inevitably encountered by large city. One of these is Malang city which has been starting to feel the congestion at various points. Many are predicting the traffic in Malang city will grow worse as in other big cites, such as Jakarta. Severe congestion in the foreseeable future will not happen if government from now on more responsive to take policy about revitalization transportion system and all facilities. The revitalization transportation system should have been anticipatory policy in order it can anticipate more congestion in the future.

Kata Kunci: Policy, Policy Formulation, Transportation, Traffic Jammed 


\section{Pendahuluan}

Kota- kota besar di Indonesia saat ini tengah dihadapkan pada berbagai macam permasalahan yang ternyata tidak hanya menjadi perhatian dan keprihatinan pemerintah daerah saja melainkan sampai pada tataran pemerintah pusat.. Mulai dari masalah kependudukan, banjir, tata ruang sampai dengan masalah kemacetan. Kemacetan menjadi masalah utama dan pelik dalam bidang transportasi di sebuah kota besar. Mulai dari DKI Jakarta, Surabaya, Bandung sampai dengan Kota Malang telah mendapati problem serupa yakni kemacetan. Banyak ahli yang memprediksi kemacetan yang terjadi saat ini dapat menyebabkan sebuah bencana yang luar biasa di bidang transportasi yakni kemacetan total yang tidak dapat terurai dan teratasi. Di sisi lain, pengguna kendaraan pribadi terutama roda dua diprediksi telah sampai pada angka 5000 lebih pada tahun ini. Pasalnya, berdasar data yang dirilis oleh Satlantas Polresta Malang disebutkan pada tahun 2008 lalu pengguna kendaraan bermotor naik drastis di angka 3.354 unit. (Dinas Perhubungan Kota Malang)

Sedangkan untuk kendaraan umum di Kota Malang tercatat sebagai berikut:

\section{Tabel 1 Data Jumlah Kendaraan \\ Umum Kota Malang tahun 2010}

\begin{tabular}{|l|c|}
\hline $\begin{array}{l}\text { Jenis Kendaraan } \\
\text { Umum }\end{array}$ & Jumlah \\
\hline $\begin{array}{l}\text { Mobil Pengangkut } \\
\text { Umum (MPU) }\end{array}$ & 1.188 unit \\
\hline $\begin{array}{l}\text { Angkutan Kota } \\
\text { (Mikrolet) }\end{array}$ & 2.236 unit \\
\hline Taksi & 281 unit \\
\hline
\end{tabular}

Sumber: Dishub Kota Malang

(dikutip dari:

(http://www.malangraya.info)

Solusi yang seringkali ditawarkan untuk mengatasi masalah kemacetan adalah dengan digelorakannya moda transportasi massal atau publik seperti moda transportasi trans Jakarta (busway) yang ada di Jakarta dan lain sebagainya. Namun berdasarkan realita yang ada, moda transportasi massal seperti busway tidak mampu mengatasi masalah kemacetan di DKI Jakarta khususnya. Untuk itu, para pengambil kebijakan di negara ini harus lebih kreatif untuk memutar otak sehingga tidak hanya penyediaan moda transportasi massal saja sebagai langkah untuk mengatasi kemacetan melainkan sebuah kebijakan antisipatif yang mampu menggeser mindset masyarakat. Karena setelah dilihat, permasalahan kemacetan tidak hanya berasal dari minimnya prasarana jalan, banyaknya penggunaan kendaraan pribadi namun lebih kepada mindset, life style atau 
budaya masayarakat itu sendiri yang mengagungkan ekslusivisme untuk menggunakan kendaraan pribadi tanpa batas. Sebagai contoh kasus, mayoritas pengendara kendaraan pribadi di DKI Jakarta terutama mobil ternyata hanya terisi satu orang saja dalam kendaraannya. Inilah yang menyebabkan kondisi jalan semakin berjubel dengan banyaknya kendaraan pribadi terutama mobil. Kondisi seperti ini harusnya dapat diatasi dengan sebuah kebijakan perubahan pola pikir dan gaya hidup yang bersifat antisipatif, terutama di kota- kota yang mulai dilanda masalah kemacetan seperti kota Malang.

Dalam artikel ini, penulis akan lebih berfokus pada masalah kemacetan yang saat ini mulai mengancam kota Malang. Tak heran jika Kota Malang adalah kota pendidikan dan salah kota besar di Indonesia. Namun, hal tersebut jika tidak segera diatasi maka beberapa tahun ke depan permasalahan kemacetan yang dapat dijumpai di DKI Jakarta dapat dirasakan di Kota Malang (Harnen Sulistyo, dalam antaranews.com)

Oleh karena itu, artikel jurnal ini ini menawarkan beberapa alternative- alternative kebijakan terkait permasalahan kemacetan di kota Malang serta beberapa kebijakan yang bersifat antisipatif terkait kemacetan yang lebih parah di Kota Malang.
PENDEKATAN (TEORI) DAN ANALISA KEBIJAKAN

Dalam menganalisa

kebijakan transportasi guna mengatasi kemacetan di Kota Malang, penulis menggunakan pendekatan analisa kebijakan publik berdasar teori dari Palumbo (1987) dimana, menggambarkan analisis kebijakan dengan komponenkomponen sebagai berikut: Agenda setting adalah tahapan dalam menganalisis dan menetapkan sifat dan besaran serta distribusi masalah. (2) Problem definition, tahapan dalam memperkirakan kebutuhan dan menetapkan area serta kelompok sasaran. (3) Policy Design (rancangan kebijakan) adalah menganalisis dan mengidentifikasikan alternative kebijakan sebagai sarana untuk mencapai tujuan kebijakan (memperoleh cost effective alternative). (4) Policy legitimation (legitimasi kebijakan) adalah menganalisis penerimaan public dan atau policy stke holder lain terhadap suatu kebijakan atau program. (5) Policy implementation (pelaksanaan kebijakan) merupakan penilaian formatif yang mengambil tempat ketika suatu kebijakan/program sedang dilaksanakan, serta menganalisis persyaratan-persyaratan yang diperlukan untuk meningkatkan kesuksesan pelaksanaan kebijakan tersebut. (6) Policy impact (dampak kebijakan) menganalisis sejauh mana pelaksanaan

suatu 
kebijakan/program memperoleh dampak seperti yang diinginkan atau ditetapkan dalam tujuan kebijakan.

(7) Termination (Penghentian kebijakan) penilaian terhadap kebijakan dan implementasinya, yang bila ternyata jelek maka kebijakan perlu dihentikan atau diganti dengan yang lain yang lebih baik.

Adapun diagram alur dalam proses analisa kebijakan publik menurut Palumbo (1987) adalah sebagai berikut:

langkah refleksi kebijakan di masa

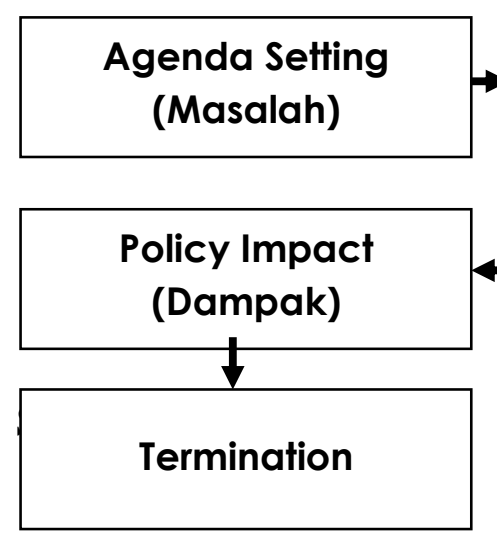

\section{DESKRIPSI MASALAH SEBAGAI MASUKAN KEBIJAN}

Upaya untuk menghasilkan informasi dan argumen, analis kebijakan dapat menggunakan beberapa pendekatan, yaitu: pendekatan Empiris, Evaluatif, dan Normatif (Dunn, 1988). Dalam menganalisa terkait permasalahan kebijakan transportasi di Kota Malang ini penulis menggunakan pendekatan empriris yang dijelaskan oleh William Dunn. Pendekatan Empiris, memusatkan perhatian pada masalah pokok, yaitu apakah sesuatu itu ada (menyangkut fakta). Pendekatan ini lebih menekankan penjelasan sebab akibat dari kebijakan publik. Selain itu, sebagai
Problem Definition

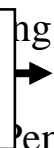

Policy Design

vano memusatkan nerhatian nada

Policy

Implementations Policy Legitimations

Pengusulan arah tindakan yang dapat memecahkan masalah problem kebijakan, merupakan inti pendekatan normatif. Jenis informasi bersifat anjuran atau rekomendasi. Untuk itu, telah dijelaskan di atas bahwa permasalahan kemacetan tidak hanya sebatas pada prasarana yang kurang memadai dan penggunaan kendaraan pribadi yang tidak ada batasnya, lebih dari itu ada beberapa masalah yang berkaitan pada kondisi sosial, ekonomi dan terlebih pada pola pikir, gaya hidup dan budaya masyarakat. Untuk fenomena kemacetan di Kota Malang ada beberapa permasalahan yang mengkonstruksi fenomena kemacetan tersebut, antara lain:

$\begin{array}{lr}\text { 1. Tingginya } & \text { angka } \\ \text { penggunaan } & \text { kendaraan } \\ \text { pribadi } & \\ \text { Untuk melihat } & \text { tingginya } \\ \text { angka } & \text { penggunaan } \\ \text { kendaraan pribadi baik di }\end{array}$


roda dua maupun roda empat sebenarnya banyak disebabkan oleh beberapa hal yakni:

a. Gaya hidup masyarakat yang eksklusif sehingga berdampak pada kegemaran dalam menggunakan kendaraan pribadi

b. Dari aspek ekonomis terkadang disebabkan oleh mudahnya pengajuan kredit kendaraan yang menyebabkan angka kepemilikan

kendaraan pribadi meningkat drastis.

2. Kota Malang merupakan kota pendidikan dan destinasi wisata

Sebagai kota pendidikan, tak heran jika kuantitas kendaraan baik roda empat ataupun roda dua banyak didominasi oleh mahasiswa, pelajar dan atau tenaga pengajar menjadikan salah satu permasalahan yang mengkonstruksi kemacetan di Kota Malang. Begitu pula, kota Malang sebagai destinasi wisata dan jalur wisata menuju kota wisata Batu mampu menjadikan salah satu penyebab kemacetan yang terjadi.
3. Adanya spot- spot pasar, parkir liar dan konsentrasi massa

Ketika melihat titik- titik kemacetan di kota Malang seketika pandangan kita langsung terarah pada tempat- tempat seperti pasar, parkir liar yang memanfaatkan dan memakan setengah bahu jalan atau tempat yang seringkali menjadi pusat massa seperti pusat perbelanjaan dan hiburan. Seperti halnya, pusat kemacetan di Kota Malang yang seringkali terdapat di sekitaran Pasar Dinoyo dan jalan Veteran sekitaran Malang Town Square dan MX Plaza serta Alun- Alun Kota dan MOG.

4. Masih terbatasnya Prasarana Jalan

Jalan yang sempit menjadi salah satu penyebab permasalahan kemacetan di Kota Malang. Kuantitas kendaraan yang tinggi dan tidak dibarengi dengan jalan yang memadai. Kita lihat saja, pada beberapa titik kemacetan di Kota Malang yang terletak di Jalan. MT. Haryono, Jalan Gajayana sampai Bendungan Sutami, Jalan Soekarno Hatta dan Jalan Veteran ternyata 
masalah selain terletak pada yang telah disebutkan di atas juga pada sarana prasarana jalan yang kurang memadai.

5. Keterbatasan Transportasi Publik

$\begin{array}{lr}\text { Berbicara } & \text { masalah } \\ \text { penyediaan } & \text { sarana }\end{array}$ transportasi publik di Kota Malang, kita hanya melihat sebatas penyediaan angkutan umum/ angkot dengan berbagai macam keterbatasan dan minimnya kenyamanan yang dirasakan oleh penumpang. Seharusnya jika kita mengcompare dengan kota- kota besar seperti halnya Surabaya dimana terdapat bus kota yang melayani rute dalam kota dan mampu menampung lebih banyak penumpang. Sehingga masyarakat sedikit merubah kebiasaannya menggunakan kendaraan pribadi ke transportasi massal. Namun, dalam realitanya di Indonesia tidak ditemukan moda transportasi publik yang nyaman dan terjangkau.

\section{ALTERNATIVE KEBIJAKAN REVITALISASI SISTEM TRANSPORTASI PUBLIK DI KOTA MALANG}

\begin{abstract}
Palumbo
(1987) menggambarkan analisis kebijakan dengan komponen-komponen sebagai berikut: (1) Agenda setting adalah tahapan dalam menganalisis dan menetapkan sifat dan besaran serta distribusi masalah. Dalam permasalahan kemacetan di Kota Malang ini, distribusi permasalahan telah dijelaskan pada point sebelumnya, dimana ada lima permasalahan krusial terkait permasalahan kemacetan di Kota Malang. (2) Problem definition, tahapan dalam memperkirakan kebutuhan dan menetapkan area serta kelompok sasaran. Dalam analisa kebijakan terkait dengan kemacetan di Kota Malang, kelompok sasaran dari kebijakan tersebut selama ini hanya sebatas masyarakat sebagai stakeholder kebijaka tersebut saja, padahal banyak partner pemerintah dalam menjalankan kebijakan tersebut. (3) Policy Design (rancangan kebijakan) adalah menganalisis dan mengidentifikasikan alternative kebijakan sebagai sarana untuk mencapai tujuan kebijakan (memperoleh cost effective alternative). Dalam menyikapi permasalahan kemacetan di Kota Malang yang mampu mendatangkan
\end{abstract}


masalah kemacetan yang lebih krusial seperti ketika kita berkaca dengan DKI Jakarta. Maka, ada beberapa alternative kebijakan yang coba ditawarkan sebagai langkah antisipatif dan solusi permasalahan kemacetan yang ada di Kota Malang untuk saat ini, antara lain:

1. Perbaikan infrastruktur dan prasarana jalan (misal pelebaran jalan) terutama di titik- titik kemacetan dan spot- spot konsentrasi massa seperti pasar, pusat pemberlanjaan dan pendidikan. Seperti, di Jalan. MT. Haryono sampai dengan Jalan. Tlogomas, Jalan. Gajayana sampai dengan Jalan. Bendungan Sutami (dengan masalah jalan sempit, banyak dimanfaatkan pasar, parkir liar dan konsentrasi massa). Dan jalan Soekarno- Hatta serta jalan. Veteran (dengan masalah taman kota yang terlalu lebar sehingga memakan luas jalan dan merupakan jalan utama yang banyak terdapat pusat perbelanjaan dan pusat pendidikan).

2. Salah satu penyebab kemacetan adalah penggunaan bahu jalan yang digunakan untuk parkir liar. Untuk memecahkan masalah tersebut diperlukan sebuah kebijakan menaikkan retribusi parkir untuk kendaraan pribadi berkali-kali lipat. Melalui mekanisme, parkir per jam. Sehingga di sisi lain, masyarakat akan berpikir 2 kali untuk lebih memilih menggunakan kendaraan pribadi dan pada akhirnya lebih memilih menggunakan transportasi publik. Kemudian, dari peningkatan retribusi tersebut yang secara langsung berdampak pada Pendapatan Daerah dapat dimanfaatkan untuk revitalisasi sarana prasarana transportasi dan penyediaan transportasi publik yang nyaman bagi masyarakat.

3. Penyediaan transportasi publik mulai saat ini yang nyaman dan terjangkau masyarakat sebagai langkah antisipatif dan jalan untuk merubah gaya hidup masyarakat dari penggunaan kendaraan pribadi ke transportasi umum. Dengan kondisi seperti ini, diharapkan gaya hidup masyarakat berubah dan penggunaan kendaraan pribadi lebih minim sehingga kemacetan yang lebih parah di masa yang akan datang sedikit teratasi mulai saat ini. 
4. Penyediaan bus dan sepeda kampus yang digunakan untuk meminimalisir penggunaan kendaraan pribadi bagi mahasiswa dan tenaga pengajar di setiap kampus yang menjadi menyumbang penyebab kemacetan di Kota Malang. Mekanismenya, disediakan bus untuk mahasiswa dan tenaga pengajar yang melayani rute antar kampus dengan jarak yang cukup berdekatan, misalnya antara Universitas Islam MalangUniversitas Brawijaya dan Universitas Negeri Malang.

5. Pengalihan jalur khusus destinasi wisata agar tidak melewati pusat kota. Hal ini berkaca pada Kota Malang sebagai salah satu jalur utama menuju kota wisata Batu dan termasuk juga sebagai destinasi wisata, sehingga diperlukan jalurjalur yang tidak terakumulasi secara sama di pusat- pusat pendidikan dan pusat perbelanjaan seperti di jalan MT. Haryono dan jalan di sekitaran Pasar Dinoyo.

Pada tahap selanjutnya, Palumbo menekankan pada adanya (4) Policy legitimation (legitimasi kebijakan) adalah menganalisis penerimaan public dan atau policy stakeholder lain terhadap suatu kebijakan atau program. Jika alternative kebijakan tersebut di implementasikan kepada masyarakat maka secara periodisasi perlu dilakukan secara berkala agar dapat diterima oleh publik, karena banyak alternative kebijakan yang perlu mendapatkan perhatian dan sosialisasi secara penuh kepada masyarakat serta publik (5) Policy implementation (pelaksanaan kebijakan) merupakan penilaian formatif yang mengambil tempat ketika suatu kebijakan/program sedang dilaksanakan, serta menganalisis persyaratan-persyaratan yang diperlukan untuk meningkatkan kesuksesan pelaksanaan kebijakan tersebut. (6) Policy impact (dampak kebijakan) menganalisis sejauh mana pelaksanaan

suatu kebijakan/program memperoleh dampak seperti yang diinginkan atau ditetapkan dalam tujuan kebijakan. Dalam pelaksanaannya, kebijakan transportasi umum di Kota Malang saat ini belum mampu mengakomodir keinginan dan kebutuhan masyarakat secara luas. Karena komposisi kendaraan umum hanya sebatas angkutan umum (MPU) yang kurang representative bagi kebutuhan dan kenyamanan masyarakat. Di sisi lain, jika alternative kebijakan tersebut di atas dapat direalisasikan maka, banyak impact atau dampak yang terjadi, baik segi positif maupun negative:

1. Secara positive, alternative kebijakan yang ditawarkan 


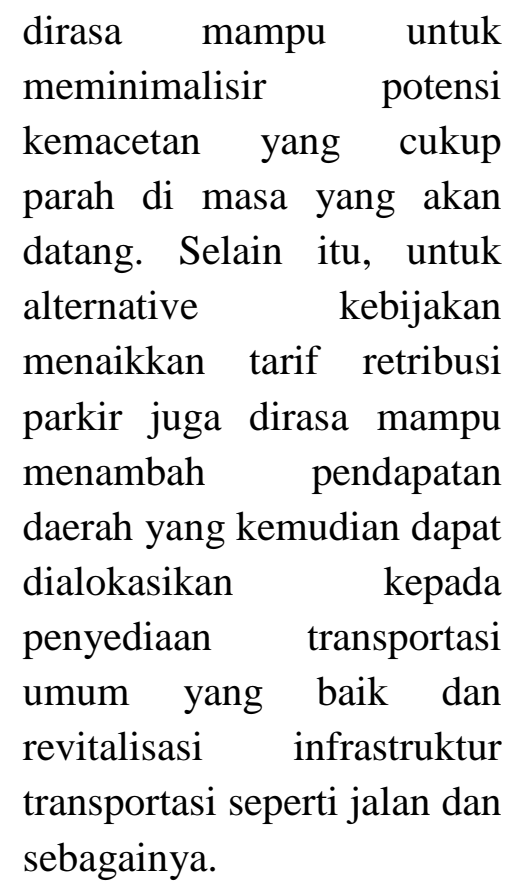

2. Secara negative, Untuk kebijakan memangkas bahu jalan atau taman kota disinyalir akan meminimalisir kebutuhan ruang hijau di tengah kota. Namun sebagai pengganti diusulkannya desain pembenahan tata ruang hijau di sepanjang jalan melalui pemberian pot- pot tanaman atau yang lain sebagainya.

3. Untuk kebijakan menaikkan tarif retribusi parkir, disinyalir akan terjadi resistensi masyarakat yang cukup kuat karena dinilai menambah beban ekonomi masyarakat.

4. Untuk kebijakan pengalihan jalan, disinyalir dapat menyebabkan potensi kemacetan baru di daerah yang akan dilewati oleh jalur destinasi wisata tersebut. Namun untuk mengatasi hal tersebut, ditawarkan pula kebijakan untuk mempersiapkan segala infrastruktur yang memadai seperti jalan yang mampu menampung kendaraan dalam jumlah yang cukup banyak dan sebagainya.

5. Untuk kebijakan penyediaan bus dan sepeda kampus, dampak yang dapat ditimbulkan adalah lembaga pendidikan seperti universitas sebagai partner pemerintah belum mampu menjalankan kebijakan tersebut dan juga kurangnya dukungan dari pengguna untuk beralih ke sepeda atau kampus.

Tahap akhir yang ditawarkan oleh Palumbo adalah (7) Termination (Penghentian kebijakan) penilaian terhadap kebijakan dan implementasinya, yang bila ternyata jelek maka kebijakan perlu dihentikan atau diganti dengan yang lebih baik.

\section{KESIMPULAN DAN SARAN}

Transportasi yang mudah dan lancar merupakan idaman bagi seluruh masyarakat, maka sangatlah beralasan jika ada beberapa pihak yang memiliki otoritas harus bisa merevitalisasi sistem ataupun sektor 
transportasi publik yang ada. Selama ini sistem transportasi khususnya di kota Malang menjadi permasalahan serius yang perlu untuk disikapi, terutama dalam hal kemacetan dan volume kendaraan yang berlebih. Untuk membuat suatu alternatif kebijakan sebagai solusi mengatasi kemacetan yang lebih parah di masa yang akan datang, pemerintah sudah selayaknya bersikap cepat, tanggap dan antisipatif sebelum kemacetan yang parah terjadi seperti di Ibukota. Perlu adanya kerjasama dari berbagai pihak untuk mewujudkan gagasan ini. Mulai dari pemerintah, pengguna jalan, dan masyarakat sebagai Stakeholder.

Saran yang dapat diberikan melalui tulisan ini untuk beberapa pihak diantaranya,

1. Bagi pemerintah, sudah sangat mendesak untuk segera memperbaiki prasarana jalan dan menyediakan sarana transportasi publik yang nyaman dan terjangkau bagi masyarakat.

2. Bagi mitra pemerintah seperti lembaga pendidikan seperti Universitas segera menyiapkan langkah taktis dan strategis untuk mendukung program pemerintah dalam rangka revitalisasi sistem transportasi untuk mengurangi kemacetan khususnya yang bersumber pada sebagian warga lembaga pendidikan yang bersangkutan misalnya mahasiswa, pelajar atau tenaga pendidik.

3. Bagi masyarakat sebagai pengguna jalan dan yang merupakan objek kebijakan, sudah harus mempersiapkan perubahan gaya hidup dan mindset dari eksklusivisme penggunaan kendaraan pribadi ke moda transportasi publik dan konsisten untuk mensukseskan kebijakan yang telah dipersiapkan oleh pemerintah ini.

\section{DAFTAR PUSTAKA}

Dunn, William. 1988. Analisa Kebijaksanaan Publik, Yogyakarta: Hanindita Press Palumbo, DJ. 1987. The Politics of Program Evaluation. Newbury Park, California: Sage

Suharto, Edi. 2010. Analisis Kebijakan Publik. Bandung: Alfabeta

Data pengguna Kendaraan Bermotor tahun 2008

http://malangraya.web.id, tanggal. akses. 01 Oktober 2016 pukul. 20.28 WIB

Harnen Sulistyo, Dekan FT UB: Malang terancam macet total http://www.antaranews.com, tanggal akses. 02 Oktober 2016 pukul. 19.15 WIB 
Transportasi Massal sebagai solusi macet

http://www.rakyatmerdekaonl ine..com, tanggal akses. 01 Oktober 2016 pukul. 20.00 WIB 